\title{
Can we have our (safe and local) cake and eat it too? Oregon re-crafts food safety regulations for farm direct marketed foods
}

\author{
Christy Anderson Brekken ${ }^{a}$ \\ Department of Agricultural and Resource Economics, Oregon State University
}

Submitted July 18, 2012 / Revised October 7 and October 29, 2012 / Accepted November 9, 2012 /

Published online February 18, 2013

Citation: Brekken, C. A. (2012). Can we have our (safe and local) cake and eat it too? Oregon re-crafts food safety regulations for farm direct marketed foods. Journal of Agriculture, Food Systems, and Community Development, 3(2), 95-108. http://dx.doi.org/10.5304/jafscd.2013.032.003

Copyright (C) 2013 by New Leaf Associates, Inc.

\begin{abstract}
Food safety regulations involve a tradeoff: the costs of regulatory compliance in exchange for a reduction in the risk of foodborne illness. But local food advocates point out that these costs have a disproportionate impact on small food producers, and that this impact threatens the viability and continued growth of the farm direct marketing sector. Oregon's farm direct marketers and local food advocates crafted new legislation to reform three areas of food safety regulatory affecting farm direct marketers: (1) licensing of the physical spaces where farm direct products are sold, (2) streamlining produce peddler licenses, and (3) deregulating specified low-risk producer-processed
\end{abstract}

${ }^{a}$ Christy Anderson Brekken, Department of Agricultural and Resource Economics; 213 Ballard Extension Hall; Oregon State University; Corvallis, Oregon 97331 USA; +1-541-7379594; brekkenc@onid.orst.edu

This paper is based on work done for the author's master's degree in Agricultural and Resource Economics at Oregon State University under advisor Dr. Larry Lev, June 2011. Ms. Brekken also holds a J.D. from the University of Minnesota (2005) and is currently working toward a Ph.D. in Applied Economics from Oregon State University. farm direct marketed products. Oregon's Farm Direct Marketing Bill, HB 2336, passed the Oregon legislature; it became effective January 1, 2012. The Oregon Department of Agriculture issued final administrative rules on June 1, 2012. After reviewing the narrow exemptions in the law and the unique characteristics of farm direct foods, it appears that Oregon's Farm Direct Marketing Bill preserves food safety while fostering the direct farm marketing sector.

\section{Keywords}

farm direct sales, farm direct marketing, farmers' market, food processing, food safety, inspection, license, local economy, local food, Oregon, policy analysis

\section{Introduction}

Food safety regulations involve a tradeoff: the costs of regulatory compliance in exchange for a reduction in the risk of foodborne illness. The costs of food safety compliance include licensing fees, planning, process modification, recordkeeping and reporting, and loss of efficiency (Antle, 2000). Even though some costs, such as 
licensing fees, are scaled to gross revenue, studies have shown that the total cost of regulation is disproportionately higher per unit of production for small and very small food producers (Antle, 2000; Hardesty \& Kusunose, 2009). Local food advocates point out that these costs increase the price of local and small-batch products, which threatens the viability of small local producers. One of the opportunity costs of one-size-fits-all food safety regulation is the size and strength of the small direct farm sector.

Policymakers across the country have recently addressed the question: Is it possible to preserve food safety while fostering the direct farm marketing sector? Can we have our safe and local cake and eat it too? By looking at the characteristics of farm direct marketed food we can find opportunities to ease regulation of that sector while continuing to mitigate the risk of foodborne illness. The purpose of this policy analysis is to show how Oregon carefully cut a small slice out of food safety regulation for farm direct foods without sacrificing food safety.

At the federal level, Congress was faced with this question during the debate over the U.S. Food and Drug Administration Food Safety Modernization Act (2011), the first federal overhaul of food safety regulation since 1938 . Consumer safety advocates called for a strengthening of food safety laws at the federal level due to several high-profile outbreaks of food poisoning in recent years. Everything from pre-prepared beef patties to peanut butter, eggs, spinach, parsley, and green onions have been the subject of food recalls and lawsuits (PricewaterhouseCoopers, 2011; Stearns, 2010). The U.S. Centers for Disease Control and Prevention (CDC) estimates that 1 out of 6 Americans will suffer from food poisoning each year, totaling 48 million cases of food-borne illnesses from 31 known pathogens, leading to 128,000 hospitalizations and over 3,000 deaths (CDC, 2011).

Meanwhile, consumers have increasingly turned to farm direct foods for a variety of personal reasons, such as a desire for fresh and healthy food, and a variety of civic reasons, such as to support local economies and to reduce the environmental impact of their food choices. As an indicator of increasing interest in local foods, the number of farmers' markets in the United States more than quadrupled from 1994 to 2012; the USDA's National Farmers Market Directory now lists 7,864 markets (USDA Agricultural Marketing Service [USDA AMS], 2012b). In 2005, farmers' markets generated an estimated USD1 billion in sales; about 25 percent of vendors surveyed reported that the farmers' market was their sole source of farm income (USDA AMS, 2006). However, farmers' markets are not the only means of farm direct marketing. Farmers sell directly to consumers through farm stands, community supported agriculture (CSA) enterprises, U-pick operations, specialty food processors, and others. Total farm direct sales in the U.S. grew by 104.7 percent from 2002 to 2007, while total agricultural sales growth in the same period was 44.4 percent (USDA AMS, 2009, Chart 5). Although these growth numbers are impressive, it is worth noting that farm direct sales make up less than 1 percent of total farm gate sales, a share that has not changed appreciably since 1982 (Lev \& Gwin, 2010). Nevertheless, local foods enjoy a high public opinion and the sector has received attention for the benefits to small farmers and local economies.

After vigorous debate over the impact of new federal food regulation on small food producers, the FDA Food Safety Modernization Act (2011) included the Tester-Hagan Amendment that created exemptions to the new food safety regulations for certain producers who sell less than USD500,000 per year and other exemptions from record-keeping and traceability requirements for farmers who sell directly to consumers or retailers within the state or 275 miles of the state line, as long as they meet the requirements of state and local laws (Bottemiller, 2010). Local and sustainable food groups had the political capital to ease new federal regulations on small local food producers at a time when concern for food safety was high.

Although balancing food safety and regulatory burdens for small producers was reactionary at the federal level, Oregon's local food advocates sensed the political strength of their growing farm direct sector and acted proactively. In Oregon, the number of farmers' markets increased ninefold between 1993 and 2012, from 18 to 163 (USDA AMS, 2012a), which was faster than the national trend 
(Stephenson, Lev \& Brewer, 2008). Oregon had the greatest percentage growth of any state in direct-marketing sales from 1997 to 2007, a 259.1 percent increase, jumping to the fifth-highest total direct-to-consumer sales volume among all states, valued at USD56 million; back in 2002, Oregon was not even in the top 10 (USDA AMS, 2009, Chart $4 \mathrm{a} \& 4 \mathrm{~b})$. The public supported local foods and farmers were becoming vocal about their struggle to grow their businesses while butting up against the food safety status quo.

Oregon was not proposing to tighten food safety regulation, but was struggling to consistently enforce the food safety laws and regulations already in place. As far back as 1999, conversations between the Oregon Department of Agriculture (ODA) and farmers' market representatives were conflicted over how to apply food safety laws to geographically dispersed, intermittent food markets consisting of many independent and diverse food purveyors. A decade later, farm direct marketing advocates asserted that the substantial increase in farmers' markets and other farm direct marketing sales in recent years had come despite laws and regulations regarding food processing, safety and sales to the public (Boutard, 2011). Through experience and direct discussions with the ODA, Oregon farmers' markets and other farm direct marketers concluded that they did not fit into the food regulatory scheme that applies to conventional food processors and retail food establishments. This lack of fit resulted in confusion (and no small part fear) about licensing and inspection requirements for farm direct marketers (Landis, 2011). The reactionary process arising from discussions with ODA grew into a proactive approach that eased existing food safety regulations.

In fall of 2009, a legislative workgroup was formed to address these issues, and shortly thereafter three farm direct marketing advocates who were also on the workgroup began drafting new legislation (R. Landis, personal communication, March 22, 2010; "Proposed Farmers' Market Concept," 2010; Taylor, 2010). The legislative working group, chaired by Rep. Matt Wingard, R-Wilsonville, put forth draft legislation in January 2011 (The
Oregonian, 2011). The Farm Direct Marketing Bill ${ }^{1}$ was passed by the Oregon House of Representatives on February 16, 2011, by a vote of 45-13. The Oregon Senate passed the bill on May 24, 2011, by a vote of $27-3$, and it was signed into law by Governor Kitzhaber on June 9, 2011. The law became effective on January 1, 2012 (Oregon House Bill [Or. HB] 2336 (Enrolled), 2011; The Oregonian, 2012). The Oregon Department of Agriculture, Food Safety Division, finalized regulations implementing the law on June 1, 2012, as discussed in detail below (Oregon Administrative Rules [OAR] 603-025-0215 to 603-025-0275, 2012).

There are three main parts of the Farm Direct Marketing Bill: (1) resolving the "venue" conflicts about licensing and inspection ambiguity for the physical spaces where farm direct products are sold, (2) streamlining produce peddler licenses, and (3) deregulating specified low-risk producerprocessed farm direct marketed products. The next three sections will discuss each of these topics in turn, outlining the problems associated with the previous food safety regulations for farm direct foods, the changes made by the Farm Direct Marketing Bill, and then evaluating the food safety implications of those changes. The final section of this policy analysis evaluates the potential impact of the Farm Direct Marketing Bill into the future, including the impact on both food safety and

\footnotetext{
${ }^{1}$ Oregon is not the only state that is differentiating regulations for conventional foods and small-scale, direct-marketed foods. Alabama, Arizona, Arkansas, Florida, Illinois, Indiana, Iowa, Kentucky, Maine, Maryland, Massachusetts, Michigan, Minnesota, New Hampshire, New Jersey, New Mexico, North Carolina, Ohio, Oklahoma, Pennsylvania, South Dakota, Tennessee, Utah, Vermont, Virginia, Washington, Wisconsin, and Wyoming have already passed or introduced legislation under the monikers "Cottage Food Bill," "Home-based Food Processor Bill," or "Pickle Bill” (Love, 2011). In 2012, California passed the "California Homemade Food Act," effective January 1, 2013 (California Assembly Bill 1616, 2012; for further information see California Department of Public Health, Cottage Food Operations: http://www.cdph.ca.gov/ programs/Pages/fdbCottageFood.aspx). Colorado enacted a similar "Cottage Food" bill in 2012 (Colorado Senate Bill 12048, 2012; for further information see Colorado Department of Public Health and Environment: http://www.colorado. gov/cs/Satellite/CDPHE-DEHS/CBON/1251586894464.)
} 
regulatory burden for small farm direct marketing businesses.

\section{Food Establishment Licensing: Venue Conflicts}

In 1999, ODA wrote the first guidelines for food safety best practices at farmers' markets, intending to monitor activity and determine the best regulatory scheme. Within a few years, ODA found itself "in a regulatory no man's land" (ODA-Farmers' Market Meeting Minutes, 2007, p. 1). The guidelines themselves were not enforceable and it was unclear how existing definitions in the food safety statutes and regulations applied to activities taking place at farmers' markets and other direct marketing venues. Under Oregon law, a food establishment license is required for any physical place that prepares, packages, stores, handles, or displays food for sale (Oregon Revised Statutes [ORS] \) 616.695(2)(a), 2010). Produce stands that are on the farmer's property have long been exempted from licensing as a food establishment (OAR 603025-0030(2)(a), 2010). These provisions were a source of regulatory ambiguity for ODA and farmers because it was unclear whether a license was required to sell a farmer's own fresh produce at the farmers' market (Boutard, 2011).

In 2007, ODA sought an opinion from the attorney general regarding the regulatory status of farmers' markets (ODA-Farmers' Market Meeting Minutes, 2007). Shortly thereafter, representatives of the farmers' markets and farm direct marketers formally met with ODA to discuss licensing requirements for farmers' markets. Although not licensed in the past, the attorney general's initial opinion indicated that farmers' markets meet the definition of a "food establishment" in the statutes and should be regulated in the same way as grocery stores and other retail food establishments (ODAFarmers' Market Meeting Minutes, 2007). Farmers' market representatives adamantly disagreed, as the market itself only negotiated physical space for direct sales from farmers to consumers. The farmers' market itself did not own or handle the land or the food at any time, and the cost to the market would only be passed on to vendors and eventually consumers.
Licensing was not immediately implemented after the 2007 meetings between ODA and farmers' market representatives. ODA's 2010 food safety guidance indicated that farmers' market management were still not required to obtain a food establishment license, but noted that "depending on the interpretation of 'food establishment'...that licensing determination might change" in the future (ODA, 2010, p. 3). ODA also did not have clear statutory authority to require a food establishment license in the case of a farmer selling only his or her own produce at a farmers' market, and indicated in guidance documents that no license was required (ODA, 2008; ODA, 2010). As farm direct marketing grew in Oregon, it was largely unregulated but under constant uncertainty about changing interpretations of existing food safety laws.

In addition to food establishment licensing, any building where prepared foods are stored before sale to the public requires a food warehouse license (ORS \ 616.695, 2010; OAR 603-025-0140, 2010). Therefore, if a farm direct marketer sent some produce to a licensed co-packer to make jam and then stored the finished jars at the farm, the law could be interpreted to require a food warehouse license to hold any on-farm inventory of the product. A question also arose as to whether inventory held for sale while at a farmers' market also requires a license.

The Farm Direct Marketing Bill resolved all ambiguity by clarifying that the physical spaces where farm direct sales take place are not subject to the food establishment licensing laws (Or. HB 2336, \2(1)(a), 2011). This applies particularly to farmers' markets, CSA drop sites, some farm stands, or other places where the sale of farm direct products take place. This part of the law makes it clear that the physical space is not regulated, but the farm direct marketer's activities may still be regulated. Furthermore, ODA has the power to inspect and enforce any applicable licenses regardless of where the farm direct marketer is offering products for sale. It is the transaction and product itself that is regulated, not the physical space where the sale takes place.

This kind of regulatory clarification is sensible in practice. A farmers' market, church parking lot, 
public street, and other places where food and money physically change hands are not proper regulatory targets. The operators of those physical places do not own the food, handle the food, or sell the food. It is akin to requiring the owner of a shopping center to obtain a food establishment license because a restaurant leases one of the spaces. The restaurant is the proper regulatory target, not the landlord who owns the entire shopping center. At a farmers' market, the person who grows, processes, and handles the food is the proper regulatory target, and it is only sensible that ODA can follow that seller to any physical venue where the product is sold to the public.

\section{Produce Dealer Licensing Exemptions for Farm Direct Marketers}

As written in Oregon law, a "retail produce peddler" is defined as "any person who sells or offers for sale or exposes for sale produce which the person has not grown or produced' (emphasis added) (ORS $\mathbb{S}$ 585.010(5), 2010). Therefore, when farm direct marketers are selling their own produce, the retail produce peddler license does not apply. A "wholesale produce dealer" is defined as "any person who deals in, handles or trades in produce and who does not operate exclusively as a grower, retailer or warehouseman" (ORS \585.010(6), 2010). The definition of a wholesale produce dealer is more ambiguous, because the farm direct marketer is not acting "exclusively as a grower, retailer, or warehouseman," but is by definition taking on at least two of those roles. The purpose of the law is to protect growers of perishable produce from abuses by retail or wholesale dealers, require prompt payment, and allow ODA to monitor and resolve violations by wholesale or retail dealers. The statutory definition is simply too broad and potentially captures an inappropriate regulatory target: the farm direct marketers who both grow and retail their own produce.

ODA food safety publications from 2008 are consistent with the statute, indicating that no licenses are required to sell fresh produce grown on a farmer's own farm, while an ODA Commodity Inspection Division (wholesale) produce dealer license is required to sell any produce not grown on the farmer's own farm (ORS \585.010(6);
ODA, 2008). In 2010, ODA guidelines indicate that a farm direct marketer may sell up to USD2,000 of fresh produce from another producer (or combination of other producers, but no thirdparty sales) (ODA, 2010). This exemption does not appear anywhere in the statute or Oregon Administrative Rules. ${ }^{2}$ The cumulative effect of the ambiguity in the statute and ODA's reinterpretation of the guidelines every few years creates uncertainty for both farm direct marketers and ODA inspectors. It potentially wastes government resources and inhibits farmers from growing their businesses.

The Farm Direct Marketing Bill removes this ambiguity by specifically exempting farm direct marketers from Produce Dealer Licensing (ORS $\$$ 585.010 to $\ 585.220,2010)$. "Farm direct marketer" is defined by statute as "an agricultural producer that sells directly to the retail purchaser the agricultural products grown, raised and harvested by that producer," whereas an agricultural producer is defined as the person primarily responsible for the "growing, raising and harvesting" of the prod-

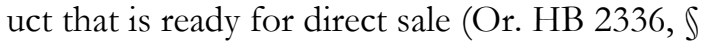
1(5); \1(2), 2011). There leaves little ambiguity that only farm direct marketers, who are the actual producers of the food, are exempt from retail and wholesale dealer license requirements.

While the Farm Direct Marketing Bill's produce dealer exemptions apply directly to the resale of produce, the bill establishes a narrower definition of consignment sales as:

an agreement under which an agricultural producer sells to the retail purchaser the agricultural products of another agricultural producer that is located in the same county as the agricultural producer, or in any county adjoining a county in which the agricultural producer is located, without representing that the products were grown or raised by the seller. (Or. HB 2336, \1(4), 2011)

\footnotetext{
2 This is based on a search of Oregon Administrative Rules for “\$2000, “exemption," "produce,” and “wholesale," and various combinations of the search terms. The guidance document does not refer to any statute or OAR creating the exemption. Other farm direct market advocates agreed that they were unaware of any rule or statute creating the exemption.
} 
Therefore, the only consignment exempted under the bill is "local" consignment — within the geographic boundaries of the counties surrounding the seller. Interestingly, a national consumer study found that over 40 percent of respondents considered food produced within one's county as "local," while in-state production was considered "regional" by a majority (Onozaka, Nurse \& Thilmany McFadden, 2010). This provides support for the "local" design of the Farm Direct Marketing bill, allowing nonregulated consignment from the same or neighboring county.

Consignment sales are similar to sales by a wholesale produce dealer in that a farmer is selling produce grown by someone else. The difference is that the wholesale produce dealer pays the grower and then resells to the retail buyer. The Farm Direct bill substitutes regulation under the wholesale produce dealer with a provision that requires title to remain with the consigning agricultural producer until the products are sold to consumers, clearly labeled with the name and address of the consignor (Or. HB 2336, \2(5), 2011). It also restricts farm direct consignment to fresh fruits, vegetables, unshelled nuts, eggs (if the consignor is licensed), and honey (Or. HB 2336, \2(3), 2011). The consigning producer does lose some of the protections of the wholesale produce dealer statute, which requires record-keeping and delivery of payment within 10 days after the sale of the products if sold on commission (ORS \585.130, 2010).

By exempting farm direct marketers from obtaining the wholesale produce dealers license, more farm direct marketers may be willing to take consignments from neighbors. The underlying law of contract and torts still applies to these transactions to protect the seller and buyer. The exception created by the Farm Direct Marketing bill is narrower than the exemption created by the 2010 ODA guidelines by keeping it "local," but the advantage is that it provides clarity about the status of farm direct marketers who take consignments and does not leave them wondering if the wholesale produce dealers license is required before they agree to sell a neighbor's produce, or whether ODA has changed its enforcement guidelines.

\section{Food Safety Licensing Exemptions for Farm Direct Marketers}

The most controversial portion of the Farm Direct Marketing Bill deregulates some types of food processing by farm direct marketers. After the 2007 meetings with the Oregon Department of Agriculture, the immediate concerns centered on the licensing of farmers' markets as retail food establishments, but local food advocates believed that it was politically feasible to address other farm direct marketing issues, such as food safety regulations, concurrently in new legislation (Boutard, 2007).

Under previous Oregon law, ODA required a food processing license if a farm direct marketer is "processing" any foods they produce. This includes licensing and inspecting commercial kitchens (OAR 603-025-0020 \& 603-025-0150, 2010; ORS \ 616.695(2)(a), 2010; ODA, 2008). ODA also inspects and licenses domestic kitchens for processing small batches of foods that will be sold to the public; this license is lower in cost but more limited in scope (ORS $\$$ 616.706, 2010; OAR 603025-0200, 2010). The regulatory definition of food processing is quite broad:

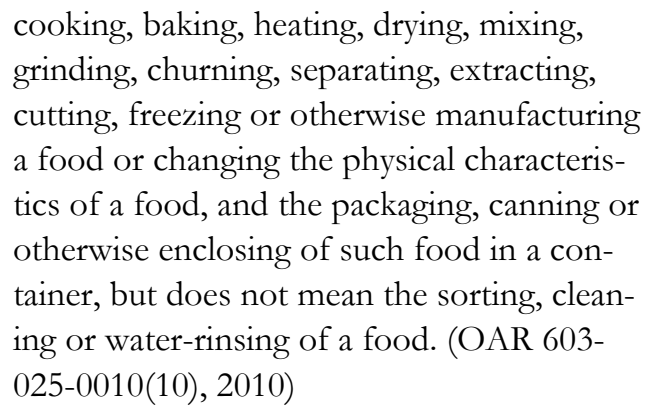

This broad definition has historically created ambiguity for farmers and ODA inspectors, as many processing activities were considered unregulated if they are done by machinery in the field, but if taken indoors are considered food processing (Landis, 2011). "There have been problems.... Sometimes inspectors weren't sure what was legal and what wasn't"' (Terry, 2011, para. 22). Typical ambiguous applications would be shelling nuts, grinding grains, and curing garlic. This kind of uncertainty created a burden on farm direct marketers who were reluctant to produce some kinds of foods due to regulatory costs. 
Indeed, Oregon farm direct marketers who grow garlic, beans, and grains have been told by farmers' market management and ODA that they need a food processing license before selling their products to the public, but point out that minimal food processing is required and the products pose very little risk of food borne illness (Landis, 2011). For example, dried beans hang on the vine to dry, but then can be separated from the shells, leaves and stems before sale to the public. If that process is interpreted as "sorting" or "cleaning," then no food processing license is required. However, if considered to be "drying" and then "separating," particularly if done in a kitchen, a food processing license is required. In the small farm direct marketing context, this is a distinction without a difference. Consider also that dried beans cannot be consumed raw, but require at least 20 minutes of cooking time in boiling water. The drying and separating of the beans is itself low-risk, but any residual food safety concerns are essentially eliminated by the required cooking time before consumption.

To take another example, Ayers Creek Farms has been featured in Mix Magazine for its polenta, a processed grain product: "the Boutard family grows the organic heirloom corn, dries it on the husk, shucks it, then stone grinds it days before selling it to their loyal customers" (Gelber, 2011, para. 1). But that drying, shucking and grinding is a form of food processing that traditionally requires a food processing license. It is understandable that there are food safety concerns whenever human processes change the character of a food, but these processes are low risk and the food can only be consumed after a substantial cooking time: "the fresh polenta (Ayers Creek) needs to cook at least $1 \frac{1}{2}$ hours to get the best results" (Gelber, 2011, para. 5).

Preserving foods through pickling or making jam is another value-added process that must occur in a licensed and inspected domestic or commercial kitchen. A farm direct marketer may be interested in turning berries or other fruit into jam for the higher profit margin that can be expected from value-added foods, but there may also be practical business motivations for turning berries into jam: cosmetically imperfect or surplus berries that are not sold fresh can be turned into a profitable product. With the licensing requirements, a farmer must invest in inspections and licensing before attempting to sell jams, or may pay a licensed copacker to process the berries even though products like jams and pickles are routinely and safely made in home kitchens. The added expenses probably do not make economic sense if the farmer is producing small or uneven quantities of fruit, and will result in a high price to the consumer.

For a final example of ambiguity in enforcement of these multiple license requirements, the 2010 ODA farmers' market food safety guidance created another nonstatutory exemption for nonpotentially hazardous foods that have been processed and packaged at a licensed facility if farmers "maintain an 'at market' inventory of $\$ 2,000$ or less" (ODA, 2010, p. 5). Again, this exception does not seem to exist in any statute or regulation. Moreover, it is not clear which ODA license the vendor would normally have to obtain. The "inventory" portion suggests that a food warehouse license may be required for "storing" the products before sale. A food establishment license may also be required, as the only clear exemption for that license appears to be for fresh produce grown on the farm direct marketer's own land. Resolving ambiguity and codifying exceptions for farm direct products provides valuable guidance to both ODA and farm direct marketers to improve the efficiency and efficacy of food safety regulation.

Under the Farm Direct Marketing Bill, certain foods can be sold directly to consumers without a food processor license (Or. HB 2336, \2(2)), including garlic and potatoes that are normally dried as part of postharvest handling; dried fruits and vegetables; shelled and unshelled nuts, and whole, hulled, crushed nuts; and ground grains legumes and seeds that are normally cooked before consumption. Shell eggs were already exempt from regulation if produced and sold from the grower's farm, so the Farm Direct Marketing bill only extends the exemption to direct sales from any venue (ODA, 2008; Or. HB 2336, \2(2)(f), 2011). Likewise, direct sales of honey required a food processor license if the grower had 20 or more colonies; the new law allows direct sales of honey regardless of the number of colonies, if not com- 
bined with other food ingredients (ODA, 2008; Or. HB 2336, \2(2)(g), 2011).

The "acidic foods" category in the Farm Direct Marketing bill allows direct sales of bottled, packaged, or canned foods that are defined as nonpotentially hazardous processed foods: (1) have a natural $\mathrm{pH}$ level of 4.6 or less (e.g., berry jam), (2) are lacto-fermented (e.g., sauerkraut), or (3) have acidity ( $\mathrm{pH}$ under 4.6) and water activity levels ( $\mathrm{a}_{\mathrm{w}}$ greater than 0.85 ) that meet federal nonpotentially hazardous food standards (e.g., dill pickles) (Or. HB 2336, \1(1); 21 C.F.R. 114.3, 2011). The third category is now commonly referred to as "acidified foods" because acid (e.g., vinegar) must be added to lower the $\mathrm{pH}$, although that term is not used anywhere in the statute or administrative rules. As a result, farm direct marketers can create and sell nonpotentially hazardous food products, including jams, fruit syrups, preserves, and low-acid canned fruits and vegetables, without getting a food processor license or domestic kitchen license. Canned goods with a $\mathrm{pH}$ over 4.6 (e.g., canned corn, green beans) must still be made by a licensed and inspected processor (ODA Food Safety Division, n.d.).

ODA's Food Safety Division began work on administrative rules to implement the Farm Direct Marketing Bill, along with other food safety bills passed in the same session that affected small and local producers. Two consecutive public comment periods were open from January to March 2012 to deal primarily with one section that was the subject of controversy in the draft rules:

OAR 603-025-0271(4): Processing and production records for products defined in 603025-0221(1)(c) [acidified foods] must show adherence to a process currently recognized by an established process authority (ODA Food Safety Division, 2012, para. 4).

On its face, this provision in the ProducerProcessed Foods Records section appears to mean that records must be available on request regarding processing time, $\mathrm{pH}$ of self-tested batches, and all other requirements showing that the acidified foods were made using technically acceptable methods. The members of the drafting committee learned instead that ODA intended that every farm direct marketer must get independent approval of their production process before selling their acidified products, including submitting the recipe and a sample to Oregon State University's (OSU) Department of Food Science and Technology Extension Service, the only process authority in the state.

Comments received during the public comment period, including those from the Oregon Farmers' Market Association, objected to the provision for several reasons: as written, it does not give farm direct marketers fair notice that they must submit recipes and samples before sale because it does not explicitly state that samples and recipes must be pre-approved; furthermore, it is in the "records" section, which implies postproduction and sales inspection. They also noted that it creates delays and places an administrative burden on both the farm direct marketer and on the process authority at OSU, which is the only process authority in the state and is not allowed to charge for services. In addition, from a legal perspective it is inconsistent with the language and intent of the Farm Direct Marketing bill (Oregon Farmers' Market Association, 2012). In effect, it is a presale inspection requirement, when the Farm Direct Marketing statute explicitly exempts defined acidified foods from licensing and inspection under the existing food safety laws.

Even after the second comment period ended on March 30, 2012, ODA's Food Safety Division further delayed finalizing the regulations until June 1, 2012. In the final version of the regulations, the controversy was resolved by incorporating several suggestions from the farm direct marketing advocates. The requirements for acidified foods were moved to one section: The Farm Direct Marketer Exception (OAR 603-025-0235). In addition to meeting all the technical requirements to ensure food safety, farm direct marketers selling acidified foods must keep batch-by-batch records of recipes and test $\mathrm{pH}$ levels in their products in accordance with FDA regulations (thus harmonizing state and federal law on food safety standards) (OAR 603025-0275(2), 2012). The implicit pre-approval from the process authority at OSU was replaced with an explicit section allowing farm direct marketers to 
use published process and product formulations created by any recognized process authority. Three examples are given in the regulation that are readily accessible and widely used, including USDA's Complete Guide to Home Canning (OAR 603-0250235(2)(B)(I-a) to (I-c), 2012). Farm direct marketers may submit their recipe and process to OSU's process authority for pre-approval, but preapproval is no longer implicitly required (OAR 603-025-0235(2)(a)(B)(II), 2012). The language of the final regulations now conforms to the language and intent of the statute, although it remains to be seen how all of the provisions will be applied in practice.

In addition to the technical food safety requirements such as $\mathrm{pH}$ and water activity levels, there are other safeguards in the law requiring that the product is controlled solely by the farm direct marketer to ensure traceability and accountability. All acidic foods must be "producer-processed products," requiring that the principal ingredients are grown, raised, harvested, and processed by the same producer (Or. HB 2336, \1(6), 2011; OAR 603-025-0225(16), 2012; 603-025-0235(2)(a)(A) \& (2)(a)(D)(ii), 2012). Furthermore, the principal ingredients may not be comingled with ingredients from a different producer (Or. HB 2336, \1(3) and 2(4), 2011). Nonprincipal ingredients do not have to be raised by the producer, but are limited to standard food preservation ingredients: "herbs, spices, salt, vinegar, pectin, lemon or lime juice, honey and sugar" (Or. HB 2336, \1(6), 2011; OAR 603-025-0225(15), 603-025-0235(2)(a)(D)(ii), 2012).

To lift the regulatory burden for only small businesses, the exemption for all acidic foods (naturally acidic, lacto-fermented and acidified) is only available if the producer sells under USD20,000 of preserved foods in the preceding calendar year (indexed to inflation) (Or. HB 2336, \2(2)(e)(D) and \3(2), 2011; OAR 603-0250235(2)(a)(D), 2012). It is intended to be a way to incubate new business lines for farm-direct products by reducing the cost of small-scale production (Terry, 2011). After the USD20,000 in annual sales is met for all acidic products combined, the processor is subject to standard ODA food processor and kitchen licensing and is assumed to be able to pay the costs of food safety regulations.
To complete the information given to consumers and enhance traceability of these foods, all preserved acid foods, eggs, honey, and grains require a label with the statements specified in statute and regulation: "THIS PRODUCT IS HOMEMADE AND IS NOT PREPARED IN AN INSPECTED FOOD ESTABLISHMENT" and "NOT FOR RESALE" in all capital, boldface type no less than one-eighth inch (Or. HB 2336, $₫$ 2(6), 2011; OAR 603-025-0265(1) \& (2), 2012). Essentially, consumers are given a warning that the only food safety assurances are those given by their relationship with the producer because the government is not overseeing the production of this particular food. In accordance with federal and state law, preserved acid foods must also be labeled with the product identity, net weight, name and address of the producer, and a list of ingredients and major allergens $($ Or. HB 2336, \2(2)(e)(C), 2011; OAR 603-025-0265(3), 2012).

As a final safeguard against improper food handling, ODA has the power to require licenses and inspection of any space or farm direct marketer that fails to keep the space in a "clean, healthful and sanitary condition" or to ensure "the condition and safety of the food the farm direct marketer provides to retail purchasers" (Or. HB 2336, \2(7), 2011; OAR 603-025-0255, 2012). “Oregon retains the right to remove the exemption to any bad actor in the state," said Rep. Matt Wingard, RWilsonville, who chaired the yearlong legislative working group that drafted the legislation (Terry, 2011). The legislature has not stripped ODA of any enforcement powers over farm direct marketers; it has only directed its preventative enforcement efforts toward potentially hazardous foods and large-scale food processors.

Although not a significant threat to public health in general, food poisoning can originate from sources that are close to home and can significantly harm the individuals affected (Magkos, Arvaniti, \& Zampelas, 2006). Consumers cannot see, smell, or test for Salmonella or E. coli before they purchase a product. In this sense, food is an example of a "market for lemons" (no pun intended) (Akerlof, 1970). In a modified version of Gresham's Law, the "risky" food drives out the "safe" food because consumers cannot effectively 
differentiate between the two categories at the time of purchase. They can only evaluate the safety of the food using indirect means, such as government regulation, safety certification labels, producer safety claims, reputation, and individual risk-benefit analysis. Government regulation is generally justified to protect consumers from food-borne illness, forcing food producers and processors to invest in food safety procedures and to achieve the four core characteristics of conventional food safety regulations: visibility, reliability, accountability, and traceability (Stearns, 2010).

But local food advocates have argued that traditional food safety regulations are not foolproof, and in some instances have gone too far by regulating some foods that are not inherently risky. The cost of the regulation on small farm businesses likely outweighs the benefits of small reductions in food-borne illness. In addition, government intervention may be unnecessary because the characteristics of the farm direct transaction are different from conventional food. Local food advocates argue that all four core characteristics of conventional food safety regulations are inherently present in the direct farm marketing transaction because of the direct relationship between buyer and seller.

Consumers have access to the producer, processor, and retailer, ensuring visibility, reliability, accountability, and traceability, together commonly referred to as trust.

The Farm Direct Marketing Bill makes rational distinctions that exempt only nonhazardous foods from regulation. The provisions defining nonhazardous foods were carefully defined in consultation with federal law and ODA food safety officials. Furthermore, the Farm Direct Marketing Bill exempts only small-batch farm direct products that are processed by farmers using only their own produce. Because local, small-batch direct food marketers are a tiny portion of the food market, they are not likely to cause a significant portion of the 48 million Americans sickened by food-borne pathogens each year. Finally, the direct relationship between the farm direct marketer and the consumer, along with the labeling safeguards in the Farm Direct Marketing bill, achieve the core goals of food safety regulation. Farm direct marketers are held to high food safety standards directly through the relationship of trust and reputation with their customers rather than indirectly through government intervention.

\section{The Future of Farm Direct Marketing and Food Safety in Oregon}

To the farm direct marketing community, the Farm Direct Marketing Bill achieves two major goals: settling the venue licensing disputes that arose every few years, and deregulating the sale of some small-scale, nonhazardous, producer-processed, direct-marketed foods. Even the list of qualifiers required to describe the Farm Direct Marketing Bill's exemptions shows that the bill is narrowly drawn. By clarifying ODA's role in statute, there is less regulatory uncertainty in addition to lifting some cost burden on the small but growing farm direct marketing sector (Terry, 2011). But we must also look at the public interest in these statutory changes: does the Farm Direct Marketing Bill ensure the public interest in food safety while also supporting the farm direct marketing sector and its concomitant civic benefits?

Farm direct marketers assert that their small sector of the food system is burdened by the costs associated with licensing and inspection (R. Landis, Corvallis-Albany Farmers' Market Manager; E. Malloy, Hillsdale Market Manager (Portland); A. Boutard, Ayers Creek Farm, personal communication, December 10, 2007). Studies have shown that the cost of regulation is higher per unit of product for small and very small food producers (Antle, 2000; Hardesty \& Kusunose, 2009). Looking only at the costs of food safety licenses in Oregon, it is easy to see the disproportionate impact on small operations. A small food processor (license type 59) with gross sales of up to USD 50,000 pays USD325 in 2012-2013. Under the Farm Direct Marketing Bill, farm direct marketers can sell up to USD20,000 of acidified products without obtaining a license. Those grossing USD20,000 to USD50,000 would pay USD325 for their license. Those with the lowest gross sales would pay 1.6 percent of their proceeds in licensing fees, while those grossing USD50,000 pay 0.65 percent of gross sales in licensing fees. Contrast that to a large food processor grossing over USD10 million, who pays USD920 for the same license, which is only 
0.0092 percent of gross sales (ODA, 2012).

Although the maximum fees for farm direct marketers are just 1.6 percent of gross sales after the Farm Direct Marketing Bill, this is only one tangible example of the disproportionate impact of regulations on small operations. Exempting the relatively small licensing fee, inspections, and any mandatory reporting eases some, but not all, of the costs of ensuring food safety for producer-processed foods.

Easing even part of the regulatory costs involved with processed food products can benefit the small farm direct marketing sector. While fresh fruits and vegetables are the mainstay of farmers' markets and other forms of farm direct marketing, they are perishable and limited in seasonality. Preserves, grains, and dried foods are a frontier for the local food movement; these kinds of products have not been the traditional fare offered by farm direct marketers. For a small farm to have a steady stream of income, expanding to some nonperishable options such as dried beans, grains, pickles, and preserves extends the market season. As an indication of the demand for year-round access to farm direct products, the USDA reported in 2010 that there were 898 winter markets (operating from November to March) in the U.S., up 17 percent from 2009 (Jones-Ellard, 2010). Many of these markets exist in cold-winter states, with New York (ranked first, with 153 markets, ahead of California), Ohio (34), Massachusetts (32), Connecticut (20), and Michigan (20) all in the top 11 states with winter markets. From the perspective of the dedicated "locavore," it is difficult to eat local throughout the year in many parts of the country, and staple foods such as grains and beans are scarce from local sources. These kinds of products are both demanded by the local consumer and increase revenue for the farm direct marketer. In Oregon, some of these "processed" foods have been unregulated in practice through ODA's lack of enforcement, but creating statutory exemptions that make sales of these foods clearly legal will remove uncertainty about future enforcement and regulation and give some farmers the confidence to expand into some of these nonperishable foods.

The cost of regulation is not borne only by food processers and their customers; public-sector costs include the administrative cost borne by taxpayers (Antle, 1999). Lifting regulations also lifts some regulatory costs for ODA, which can be characterized as a trade-off between foods safety and public funds. As pointed out by Dr. Paul Cieslak, head of the communicable disease program at the Oregon Public Health Division: "The risk of getting sick from any single portion of food is probably small, and there are fixed costs with doing an inspection.... At some point, the inspection doesn't become worth it anymore" (Terry, 2011, para. 13). The government has limited resources to spend on preventative food safety regulation, so the Farm Direct Marketing Bill directs the use of public funds at the high-risk food safety issues, such as large processors who take ingredients from many sources, and potentially hazardous foods and processing methods. Clarifying the law for ODA is an equally important policy consideration.

It is instructive that the Farm Direct Marketing Bill came about through a deliberative process, including a year-long legislative work group where all interested parties were at the table. The exemptions were crafted following FDA and ODA guidelines regarding hazardous foods. As a result, "state epidemiologists, who investigate food poisoning, are not worried about the exemption to inspections" (Terry, 2011, para. 12). ODA's food safety administrator, Vance Bybee, who has been involved with these issues for several years, has stated: "We're not expecting folks will be doing anything different....We think they still will follow the standards. The only difference is we won't require a license and we won't be out to inspect their facilities" (Lies, 2011).

Although a tiny percent of the food consumed in Oregon will be made under the Farm Direct Marketing exemption, there are two outcomes from the law that could be significant. First, although we tend to measure food safety outbreaks in the thousands of cases, even one serious case is devastating to the person or family who falls ill. If food-borne illness is caused by foods made under the Farm Direct Marketing Bill exemptions, it could mean increased enforcement activity by ODA against all exempt food processors, calls to 
repeal the exemptions, and loss of public trust in farm direct marketed products.

The other significant outcome of the Farm Direct Marketing Bill is also measured in impacts to a small number of people — the farm direct marketers in the state. Although farm direct marketed food is still less than 1 percent of agricultural products sold, the majority of the farms in Oregon are characterized as small. The USDA's 2007 Census of Agriculture found that 72.6 percent of the farms in Oregon operate on less than 100 acres (40.5 ha). In terms of farm sales, 67.5 percent of farms report sales under USD10,000, and the next 15.6 percent of farms report sales of USD10,000 to USD49,999 (USDA Economic Research Service, n.d.; the next census of agriculture will occur in 2012). There is a large pool of farms that have a new opportunity to create product lines under the Farm Direct Marketing Bill exemptions, but it is likely that only a small number will take advantage of those opportunities. The number of farms that will try exempt processing and sales is an open question, and there may be a delay before consumers start seeing the labels at their local farmers' market or farm stand. But expanding product lines and adding to the farm's bottom line can make a big difference for individual farmers trying to make a viable small farm business work.

Oregon's Farm Direct Marketing Bill fulfills many public-policy concerns using economically and politically justifiable means. It exempts lowrisk, small-batch food processing and direct sales; the farm direct marketing transaction itself and the bill's requirements provide adequate information for consumers to make informed choices about their own exposure to food risk; and it strikes a balance between supporting small local farms and their accompanying civic benefits while protecting the public from high-risk food processing and sales. After a yearlong deliberative process that included state regulators, farmers' market representatives, and small local farm direct marketers, the bill is now Oregon law and is in the implementation phase. All parties seem to agree on one point: "It's a good bill....It does what everybody wanted it to do-clarify what the law is" (A. Boutard quoted by Terry, 2011, para. 30).

\section{References}

Akerlof, G. A. (1970). The market for "lemons": Quality uncertainty and the market mechanism. The Quarterly Journal of Economics, 84(3), 488-500. http://dx.doi.org/10.2307/1879431

Antle, J. M. (1999). Benefits and costs of food safety regulation. Food Policy, 24(6), 605-623. http://dx.doi.org/10.1016/S0306-9192(99)00068-8

Antle, J. M. (2000). No such thing as a free safe lunch: The cost of food safety regulation in the meat industry. American Journal of Agricultural Economics, 82(2), 310-322. http://dx.doi.org/10.1111/0002$\underline{9092.00027}$

Bottemiller, H. (2010, December 22). Food safety bill heads to president's desk. Food Safety News. Retrieved from http://www.foodsafetynews.com/ 2010/12/food-safety-bill-clear-final-hurdle-headsfor-presidents-desk/

Boutard, A. (2007, April 2). Letter to Michael Govro, Food Safety Division, Oregon Department of Agriculture. Copy via email forwarded by Rebecca Landis, December 7, 2007. On file with author.

Boutard, A. (2011, February 2). Testimony of Anthony Boutard in support of HB 2336 before the [Oregon] House Committee on Agriculture and Natural Resources. On file with author.

Centers for Disease Control and Prevention [CDC]. (2011, February 4). CDC 2011 Estimates: Findings. CDC Estimates of Foodborne Illness in the United States, Table 1. Retrieved from http://www.cdc.gov/ foodborneburden/2011-foodborne-estimates.html

Gelber, T. (2011, February). Cook this now: Polenta with caramelized onions, kale and fontina. Mix Magazine. Retrieved from http://www.oregonlive. $\mathrm{com} / \mathrm{mix} /$ index.ssf/people-events-stuff/cook-thisnow-polenta-with-caramelized-onions-kale.html

Hardesty, S., \& Kusunose, Y. (2009). Growers' compliance costs for the Leafy Greens Marketing Agreement and other food safety programs [University of California Small Farm Program Research Brief]. Retrieved from the UC Small Farm Program website: http://sfp.ucdavis.edu/files/143911.pdf

Jones-Ellard, S. (2010, December 8). USDA highlights nearly 900 operating winter farmers markets; many markets located in cold-weather states [Press release]. Retrieved from http://www.ams.usda.gov/ 
Landis, R. (2011, February 2). Testimony of Rebecca Landis before the [Oregon] House Committee on Agriculture and Natural Resources. On file with author.

Lev, L., \& Gwin, L. (2010). Filling in the gaps: Eight things to recognize about farm-direct marketing. Choices: The Magazine of Food, Farm and Resource Issues, 25(1). Retrieved from http://www.choices magazine.org $/$ magazine $/$ article.php?article $=110$

Lies, M. (2011, May 4). Oregon Senate takes up small farm bills. Capital Press. Retrieved from http://www.capitalpress.com/mobile/BRIEF-ml$\underline{\text { small-farm-bills-050611 }}$

Love, D. (2011, April 19). States advocate for legislation and regulation to support home-based microprocessing. Retrieved from the Farmers Market Coalition website: http:// farmersmarket coalition.org/states-advocate-for-legislation-andregulation-to-support-home-based-microprocessing/

Magkos, F., Arvaniti, F., \& Zampelas, A. (2006). Organic food: Buying more safety or just peace of mind? A critical review of the literature. Critical Reviews in Food Science and Nutrition, 46(1), 23-56. http://dx.doi.org/10.1080/10408690490911846

Onozaka, Y., Nurse, G., \& Thilmany McFadden, D. (2010). Local food consumers: How motivations and perceptions translate to buying behavior. Choices: The Magazine of Food, Farm and Resource Issues, 25(1). Retrieved from http://www.choices magazine.org $/$ magazine $/$ article.php?article $=109$

Oregon Administrative Rules 603-025-0010 et seq. [Food Establishment Standards and Standards for Retail Food Service Activities]. (2010).

Oregon Administrative Rules 603-025-0140 [Food Storage Warehouses]. (2010).

Oregon Administrative Rules 603-025-0215 to 603-0250275 [Farm Direct Marketing Rules]. (2012, June 1).

Oregon Department of Agriculture - Farmers' Market Meeting Minutes. (2007, March 28). Meeting held at the Food Innovation Center, Portland, Oregon. On file with author.

Oregon Department of Agriculture. (2008). Keeping food safe at local farm direct markets: Food safety tips for Oregon food producers. On file with author (no longer posted on ODA website).

Oregon Department of Agriculture. (2010, June). Food safety at farmers markets: 2010 market season information and guidelines. On file with author (no longer posted on ODA website).

Oregon Department of Agriculture. (2012). Licensing and inspections: License fee structure July 1, 2012June 30, 2013. Retrieved from http://oregon.gov/ ODA/FSD/licensing.shtml\#License fee structure _July_1_2012__June_30_2013

Oregon Department of Agriculture Food Safety Division. (n.d.). Farm Direct FAQ. Retrieved from http://www.oregon.gov/ODA/FSD/faq 2336. $\underline{\text { shtml }}$

Oregon Department of Agriculture Food Safety Division. (2012, January). Notice of Proposed Rulemaking Hearing and Draft Farm Direct Marketing Rules. On file with author.

Oregon Farmers' Market Association. (2012, March 30). Testimony of Rebecca Landis, president, Oregon Farmers' Markets Association, regarding proposed rules for the Farm Direct Bill - adoption of OAR 603-025-0225 to 603-025-0275. On file with author.

Oregon House Bill 2336 (Enrolled). (2011). Text available at http://www.leg.state.or.us/11 reg/ measures/hb2300.dir/hb2336.en.html

Oregon Revised Statutes \585.010 to 585.990 [Agricultural Marketing and Warehousing; Produce Peddler Licenses]. (2010).

Oregon Revised Statutes $₫ 616$ [Food Establishment Standards and Standards for Retail Food Service Activities]. (2010).

Oregon Revised Statutes $\ 616.695$ [Food Storage Warehouses]. (2010).

The Oregonian. (2012). Your Government: House Bill 2336. Retrieved from http://gov.oregonlive.com/bill/2011/HB2336/

PricewaterhouseCoopers. (2011, January). Point of view: FD A Food Safety Modernization Act [Food Safety Series]. Retrieved from http://www.pwc.com/ us/en/issues/food-safety-modernizationact/assets/pov-food-safety-modernization-actvfinal.pdf

"Proposed Farmers' Market Concept as of 5/25/2010." (2010). On file with author.

Stephenson, G., Lev, L., \& Brewer, L. (2008). When things don't work: Some insights into why farmers' markets close [Extension \& Experiment Station Communication Special Report 1073-E]. Retrieved from http://extension.oregonstate.edu/catalog/ $\mathrm{pdf} / \mathrm{sr} / \mathrm{sr} 1073$-e.pdf 
Stearns, D. W. (2010). On (cr)edibility: Why food in the United States may never be safe. Stanford Law \& Policy Review, 21, 245-275.

Taylor, C. D. (2010, October 6). Memo to Beth Herzog, Administrator, House Interim Committee on Agriculture, Natural Resources and Rural Communities, from Charles Daniel Taylor, Senior Deputy Legislative Counsel, regarding LC 1051 redraft. On file with author.

Terry, L. (2011, February 16). Rules for Oregon farmers markets, formerly homegrown, could soon be law. The Oregonian. Retrieved from http://www.oregonlive.com/health/index.ssf/2011 /02/rules_for_oregon_farmers_marke.html

United States Department of Agriculture, Agricultural Marketing Service. (2006). USD A releases new farmers market statistics [Press release AMS No. 281-06]. Washington, D.C.: USDA AMS. Retrieved from http://www.ams.usda.gov/

United States Department of Agriculture, Agricultural Marketing Service. (2009). Facts on direct-to-consumer food marketing: Incorporating data from the 2007 census of agriculture [PDF document]. Retrieved from http://www.ams.usda.gov/AMSv1.0/getfile?dDoc $\underline{\text { Name }=\text { STELPRDC5076729 }}$
United States Department of Agriculture, Agricultural Marketing Service. (2012a). Farmers' market search: Oregon [Map and count of all Oregon farmers' markets]. Retrieved from http://apps.ams.usda.gov/FarmersMarkets/google Map.aspx?'state $=$ OREGON

United States Department of Agriculture, Agricultural Marketing Service. (2012b, August 3). USDA directory records more than 7,800 farmers markets; national resource helps more Americans connect with local farmers [Press release]. Retrieved from http://www.ams.usda.gov/

United States Department of Agriculture, Economic Research Service. (n.d.). Census of agriculture: State Fact Sheets: Overview: Oregon. Retrieved May 2, 2012, from http://www.ers.usda.gov/dataproducts/state-fact-sheets/state-data.aspx? $\underline{\text { StateFIPS }=41 \& \text { StateName }=\text { Oregon }}$

U.S. Food and Drug Administration [FDA] Food Safety Modernization Act, 21 U.S.C. \27, Pub. L. No. 111-353, 124 Stat. 3885 (2011). 